JURNAL PENELITIAN

\title{
PENERAPAN GAYA KEPEMIMPINAN DEMOKRATIK TERHADAP PENINGKATAN KINERJA APARATUR PADA DINAS PERHUBUNGAN,KOMUNIKASI DAN INFORMATIKA KABUPATEN KEPULAUAN MENTAWAI
}

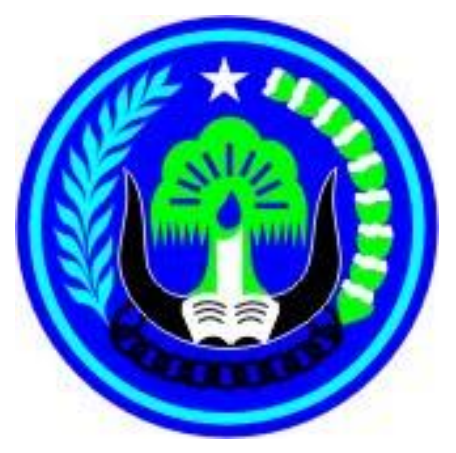

Disusun Oleh :

Sayid Anshar, SHI, MH.

NIDN. 1025078102

FAKULTAS ILMU SOSIAL DAN ILMU POLITIK UNIVERSITAS EKASAKTI

2019 


\title{
PENERAPAN GAYA KEPEMIMPINAN DEMOKRATIK TERHADAP PENINGKATAN KINERJA APARATUR PADA DINAS PERHUBUNGAN,KOMUNIKASI DAN INFORMATIKA KABUPATEN KEPULAUAN MENTAWAI
}

\author{
Sayid Anshar, SHI, MH. \\ Email ancasaid14@gmail.com
}

\begin{abstract}
ABSTRAK
Permaslahan dalam penelitian ini adalah sejauh mana pengaruh kepemimpinan Dinas Perhubungan, Komunikasi dan Informatika Kabupaten Kepulauan Mentawai dalam meningkatkan kinerja Pegawai Negeri Sipil di Dinas Perhubungan, Komunikasi dan Informatika Kabupaten Kepulauan Mentawai, kendala yang ditemui dalam pelaksanaanya serta upaya-upaya apa sajakah yang dilakukan untuk meningkatkan kinerja tersebut.

Metode yang digunakan dalam penelitian ini adalah metode Deskriptif, Kualitatif, Populasi penelitian ini adalah Pegawai yang ada dalam lingkungan Dinas Perhubungan, Komunikasi dan Informatika Kabupaten Kepulauan Mentawai, yang sampelnya terdiri dari 8 orang yaitu : 1). Kepala Dinas Perhubungan, Komunikasi dan Informatika, 2). Sekretaris, 3). Kasubag Umum dan Kepegawaian, 4). Kasubag Keuangan, 5). Kepala Bidang Perhubungan Darat dan Udara, 6). Kepala Bidang Perhubungan Laut, 7). Kepala Bidang Perhubungan Kominfo, 8). StafTeknik Pengumpulan Data melalui study lapangan ( oberasi dan wawancara )

Sumber data dalam penelitian ini terdiri dari atas 2 yakni Sumber Data Primer dan Data Skunder. Waktu Penelitian 2 Bulan, berlokasi di Dinas Perhubungan, Komunikasi dan Informatika Kabupaten Kepulauan Mentawai.Berdasarkan hasil penelitian terungkap bahwa masih ada sebagian Pegawai di Dinas Perhubungan, Komunikasi dan Informatika Kabupaten Kepulauan Mentawaiyang belum memenuhi Kinerja PNS yang sudah ada, semua itu karena kurangnya kesadaran dan rasa tanggung jawab terhadap tugas yang diberikan atasan.
\end{abstract}

Kata Kunci : pengaruh kepemimpinan, peningkatan kinerja Pegawai Negeri Sipil 


\begin{abstract}
The problem in this research is the extent of the influence of the leadership of the Department of Transportation, Communication and Information of the Mentawai Islands Regency in improving the performance of Civil Servants in the Department of Transportation, Communication and Information of the Mentawai Islands Regency, the obstacles encountered in its implementation as well as what efforts have been made to improve that performance.

The method used in this research is descriptive, qualitative, the population of this study are employees in the Department of Transportation, Communication and Information Mentawai Islands Regency, the sample consists of 8 people, namely: 1). Head of Department of Transportation, Communication and Information, 2). Secretary, 3). Head of General Affairs and Staffing, 4). Head of Finance, 5). Head of Land and Air Transportation, 6). Head of Sea Transportation, 7). Head of Communication and Communication Sector, 8). Data Collection Engineering Staff through field studies (operations and interviews).

Sources of data in this study consisted of 2 namely Primary Data Sources and Secondary Data. Research Time 2 Months, located in the Department of Transportation, Communication and Information Mentawai Islands Regency. Based on the results of the study revealed that there are still some employees in the Department of Transportation, Communication and Information Mentawai Islands Regency who have not met the existing performance of civil servants, all because of a lack of awareness and a sense of responsibility towards the tasks given by the boss.
\end{abstract}

Keywords: leadership influence, performance improvement of Civil Servants

\title{
A. PEndahuluan
}

\subsection{Latar Belakang Masalah}

Keberhasilan organisasi pemerintah daerah dalam menjalankan fungsinya merupakan kontribusi langsung dari prilaku pegawainya, oleh karena itu pegawai yang bekerja pada pemerintah harus dikembangkan sebaiknya, melalui peningkatan kompetensinya, sehingga setiap aparatur pemerintah profesional dalam menjalankan tugasnya senantiasa memiliki komitmen dan loyalitas yang sama dan kuat untuk memenuhi seluruh aspek pelayanan publik dengan merubah sikap dan perilaku, serta penataan sistem pelayanan yang 
efektif dan efesien, sehingga aparatur pemerintah secara optimal dapat memberikan pelayanan publik kepada masyarakat. Untuk mewujudkan hal tersebut maka diperlukan suatu gaya kepemimpinan yang dapat meningkatkan kinerja terhadap aparatur dibawahnya dalam rangka mencapai tujuan organisasi.

Dengan melalui Dinas Perhubungan, Komunikasi dan Informatika Kabupaten Kepulauan Mentawai yang merupakan instansi pemerintahan yang memberikan jasa publik melalui sistem pelayanan terhadap kebutuhan masyarakat. Sebagai salah satu infrastruktur atau pengembangannya kegiatannya memerlukan suatu rencana berjangka panjang yang bersifat umum dan berkaitan dengan kondisi fisik daerah Kabupaten Kepulauan Mentawai, serta dimensi-dimensi dan rencana tata ruang atau kawasan yang bersangkutan.

Sehingga untuk mencapai kinerja atau prestasi kerja pegawai yang maksimal, perlu kepemimpinan yang tepat dari atasan, sebagai faktor utama yang dapat menggerakkan, mengarahkan, membimbing dan memotivasi pegawai untuk lebih berprestasi dalam bekerja. Pemimpin dapat mempengaruhi moral, kepuasan kerja, keamanan, kualitas kehidupan kerja dan terutama tingkat prestasi suatu organisasi.

Berdasarkan latar belakang permasalahan yang di paparkan diatas, maka menarik untuk dilakukan penelitian tentang "Penerapan Gaya Kepemimpinan Demokratik Terhadap Peningkatan Kinerja Aparatur Pada Dinas Perhubungan, Komunikasi Dan Informatika Kabupaten Kepulauan Mentawai".

\subsection{Rumusan Masalah}

Berdasarkan rumusan masalah diatas, maka penulis merumuskan masalah penelitian sebagai berikut : (1). Bagaimana Penerapan Gaya Kepemimpinan Demokratik Terhadap Peningkatan Kinerja Aparatur Pada Dinas Perhubungan, Komunikasi Dan Informatika Kabupaten Kepulauan 
Mentawai? (2). Kendala yang ditemui dalam Penerapan Gaya Kepemimpinan Demokratik Terhadap Peningkatan Kinerja Aparatur Pada Dinas Perhubungan, Komunikasi Dan Informatika Kabupaten Kepulauan Mentawai? (3). upaya apa saja yang digunakan dalam mengatasi kendala-kendala dalam penerapan Gaya Kepemimpinan Demokratik Terhadap Kinerja Aparatur Pada Dinas Perhubungan, Komunikasi Dan Informatika Kabupaten Kepulauan Mentawai?

\section{B. KAJIAN PUSTAKA}

\subsection{Manajemen}

Taylor adalah orang pertama yang mengembangkan manajemen ilmiah.Taylor terkenal sebagai Bapak Manajemen Ilmiah karena hasil penelitiannya yang telah dibukukan tentang usaha-usaha untuk meningkatkan produktivitas kerja berdasarkan waktu dan gerak pada tahun 1886, dijadikan sebagai pegangan penting bagi para pegawai dan pemimpin. Dalam penelitiannya itu, ia berpendapat bahwa efesiensi pemerintahan rendah karena banyak waktu dan gerak-gerak pengawai yang tidak produktif.

Selain itu, taylor telah memberikan prinsip-prinsip dasar penerapan pendekatan ilmiah dalam manajemen dan mengembangkan teknik-teknik untuk mencapai efisiensi dan keefektifan organisasi. Ia berasumsi bahwa manusia harus diperlakukan seperti mesin. Dalam bekerja, setiap manusia harus diawasi oleh supervisor secara efektif dan efisien.

Kritik yang sangat keras dari para ahli perilaku yang mengecam penganut Taylor menyatakan bahwa Taylor dan penganutnya telah memperlakukan para pekerja secara tidak manusiawi.Untuk mengatasi kelemahan pendekatan manajemen klasik, muncul pemikiran para ahli berikutnya dengan pendekatan baru yang disebut teori organisasi klasik.

\subsection{Kepemimpinan}

Kepemimpinan dalam bangsa Indonesia berasal dari kata pemimpin yang artinya bimbing atau tuntun. Kata pimpin melahirkan kata kerja memimpin dan kata benda pemimpin, yakni orang yang memimpin, membingbing, atau 
menuntun. Kepemimpinan terjadi jika ada pemimpin mempengaruhi pengikutnya. Pemimpin merupakan unsur esensial dalam kepemimpinan, tanpa pemimpin tidak ada kepemimpinan.

Pemimpin adalah orang yang memimpin, atau seseorang yang karena kecakapan-kecakapan pribadinya dengan atau tanpa pengangkatan resmi dapat mempengaruhi kelompok yang dipimpinnya untuk mengerahkan upaya bersama kearah pencapaian sasaran-sasaran tertentu. Fairchilid menyatakan bahwa pemimpin ialah seoarang yang memimpin, dengan jalan memprakarsai tingkah laku sosial dengan mengatur, mengarahkan, mengorganisir atau mengontrol usaha/ upaya orang lain, atau melalui prestise, kekuasaan, atau posisi.

Selanjutnya Ndraha menjelaskan bahwa kepemimpinan adalah : "Kemampuan seseorang ( suatu pihak ) untuk mempengaruhi orang lain melalui dirinya sendiri dengan cara tertentu sehingga ( agar ) prilaku orang itu berubah atau tetap, menjadi integratif. Berbagai dimensi menyangkut kepemimpinan meliputi :

1. Kemampuan seseoarang untuk mempengaruhi orang lain, yang indikatornya meliputi sistem nilai kepemimpinan seperti : usia, status social, kepandaian, eksternal, gelar, keterampilan, senioritas, kekuatan fisik, kekayaan, keteladanan, moralitas, disiplin, pendirian, pengorbanan, pengalaman, kearifan, kerja sama, kebersamaan, dan keterbukaan.

2. Cara mempengaruhi oaring lain, dimana indikatornya meliputi kemampuan apa yang digunakan, seberapa besar dan dengan cara bagaimana.

3. Prilaku orang lain yang indikatornya menyangkut berubah, tetap, atau meningkat.

4. Fakta pencapaian tujuan, yang indikatornya adalah kesejahteraan masyarakat, stabilitas pemerintahan, dan hubungan 


\subsection{Teori Kepemimpinan}

Teoeri ilmu kepemimpinan sangat banyak dan variasi pokok permaslahannya. Berikut ini akan dibahas teori-teori kepemimpinan yang bersifat umum:

\section{Teori Genetic ( Greatman Theory Of Leadership )}

Menurut teori ini dalam setiap masyarakat lahir orang besar yang sudah ditakdirkan untuk menjadi pemimpin masyarakat. Para pemimpin merupakan oarang yang dilahirkan dengan takdir untuk jadi pemimpin. Ketika dilahirkan meraka telah mempunyai kemampuan untuk memimpin. Kemampuan ini lahir karena faktor keturunan.

2. Teori Sifat Pemimpin

Sifat adalah karakteristik kejiwaan dan fisik yang telah dibawa sejak lahir dan karateristik yang diperoleh oarang dari lingkungannya. Dimensi karakteristik kejiwaan adalah keadaan jiwa yang mendasari orang berpikir, bersikap, berprilaku, dan berkemampuan tetentu. Dimensi karakteristik fisik anatara lain keadaan jasmani seseoarang seperti jenis kelamin, tinggi, berat badan, bentuk tubuh, kecantikan dan kegagahan, kesehatan fisik, energi, dan stamina. Sedangkan karakteristik yang diperoleh dari lingkungan adalah ilmu pengetahuan dan keterampilan.

3. Teori Kepemimpinan Transaksional ( Transactional Leadership Theory)

Pemimpin dan pengikut mempunyai tujuan yang sama, namun demikian tingkat atau level motivasi dan potensi untuk mencapai tujuan tesebut berbeda. Kepemimpinan mentranformasi berusaha mengembangkan sistem yang sedang berlangsung dengan mengemukakan visi yang mendorong berkembangnya masyarakat baru dan akhirnya mengajarkan para pengikut bagaimana menjadi pemimpin dengan melaksanakan peran aktif dalam perubahan. Ikut seratanya pengikut dalam perubahan secara aktif membuat pengikut menjadi pemimpin.

4. Teori Kepemimpinan Transaksional ( Transactional Leadership Theory ) 
Teori ini mendasarkan diri pada asumsi bahwa kepemimpinan merupakan kontrak sosial antara pemimpin dan pengikutnya. Pemimpin dan pengikut merupakan pihak-pihak yang mempunyai tujuan, kebutuhan dan kepentingan sendiri. Hubungan pemimpin dengan pengikut merupakan hubungan trasnsaksi, yaitu menukarkan sesuatu yang dibutuhkan para pengikutnya.

5. Teori Kepemimpinan Kharismatik

Menurut Weber menjelaskan " Kepemimpinan kharismatik mempunyai kapasitas untuk merubah sistem sosial yang ada berdasarkan persepsi pengikut yang percaya pada pemimpin ditakdirkan mempunyai kemampuan istimewa. Sementara itu House mengatakan bahwa pemimpin kharismatik merupakan orang yang dominan, percaya diri, butuh mempengaruhi, dan percaya kebenaran kepercayaannya. Pemimpin kharismatik sangat berpengaruh.

6. Teori Kepemimpinan Situasional ( Situational Ladership Theory )

Teori ini disebut juga contingency theory of ladership. Teori ini berpendapat bahwa kepemimpinan yang efektif tergantung pada sejumlah faktor tertentu. Tidak ada kepemimpinan yang efektif untuk semua situasi atau keadaan. Siagian mengatakan " Efektifitas kepemimpinan seseorang juga sangat ditentukan oleh kemampuannya mengenali secara tepat kondisi yang dihadapinya, baik kondisi yang terdapat dalam organisasi maupun kondisi yang terdapat diluar organisasi tetapi mempunyai dampak bagi jalannya roda organisasi yang bersangkutan. Situasi atau keadaan pengikut, tugas kelompok, norma organisasi, dan lingkungan organisasi. Kepemimpinan yang situasional berarti sekaligus memperhitungkan faktor kondisi, waktu, dan ruang yang turut berperan dalam menentukan pilihan gaya kepemimpinan yang paling tepat agar kepemimpinannya efektif. 


\section{Teori $\mathrm{X}$ dan Teori $\mathrm{Y}$}

Teori $\mathrm{X}$ berasumsi bahwa pada hakekatnya manusia itu pemalas dan tidak termotivasi untuk bekarja. Manejer yang mempunyai asumsi ini bersikap negatif terhadap para bawahannya. Oleh karna itu prilakunya dalam memimpin mereka mempergunakan teknik mempengaruhi menekutnakuti, mengancam, dan memaksa serta mengontrol mereka dengan ketat. Sebaliknya teori Y berasumsi bahwa manusia pada hakekatnya senang dan termotivasi untuk bekerja. Manajer yang mempunyai asumsi ini bersifat positif terhadap bawahannya. Prilaku kepemimpinannya dalam mempengaruhi bawahannya tidak mempergunakan taktik memaksa.

\section{METODE PENELITIAN}

\subsection{Metode Yang Digunakan}

penelitian ini menggunakan metode yang bersifat deskriptif kualitaf. Sementara itu menurut Fahri Ali penelitian dekriptif merupakan metode penelitian yang melukiskan sifat-sifat individu, suatu keadaan, dan sebagainya yang merupak objek penelitian. Selanjutnyadan Farid Ali menjelaskan, bahwa metode penelitian kualitattif adalah penelitian atau metode yang berpangkal dan peristiwa social yang akan hakikatnya, tidak bersifat eksternal, atau metode yang dilakukan berdasarkan analisa pertimbangan logika dan rasional serta mengandalkan keberlakuan teori dan dalil yang berlaku secara umum.

\subsection{Populasi dan Sampel}

a. Populasi

Populasi merupakan keseluruhan objek yang akan diamati dalam suatu kegiatan penelitian. Menurut Nawawi, populasi adalah keseluruhanobjek penelitian yang terdiri dari manusia, benda-benda, hewan, tumbuhan, gejalagejala sosial karaktristik tertentu dalam suatu penelitian, Adapun populasi dalam penelitian ini adalah pegawai yang ada dalam lingkungan Dinas Perhubungan, Komunikasi dan Informatika Kabupaten Kepulauan Mentawai b. Sampel 
Menurut Notoadmojo,sampel adalah sebagian yang mewakili dari keseluruhan obyek yang diteliti dan dianggap mewakili seluruh populasi, Adapun Sampel dalam penelitian ini adalah dengan menggunakan metode Probabilitas sampling karena tidak semua propabilitas yang jadi responden, maka dalam hal ini penulis memilih responden secara kualitatif yang mewakili individu dari bagian populasi yang ada di lingkungan Dinas Perhubungan Komunakasi dan informatika Kabupaten Kepulauan Mentawai Sebanyak 5 orang diantaranya : Kasubag Umum dan kepegawaian, kabid Darat, kabit Laut,Kabid Kominfo, Staf Kominfo.

\subsection{Teknik Pengumpulan Data}

a. Studi Kepustakaan

Adalah teknik pengumpulan data dengan dua cara. Pertama, melakukan kajian literature beberapa buku yang berhubungan dengan permasalahan penelitian.Kedua, melakukan kajian beberapa dokumen yang berhubungan dengan peranan kepemimpinan dalam meningkatkan disiplin pegawai di Dinas Perhubungan, Komunikasi dan Informatika Kabupaten Kepulauan Mentawai.

b. Studi Lapangan

\section{Observasi}

Kegiatan yang dilakukan dalam pengamatan ini adalah mencari dan memahami sitiasi objek penelitian yang berkaitan dengan peranan kepemimpinan dalam meningkatkan disiplin pegawai di Dinas Perhubungan, Komunikasi dan Informatika Kabupaten Kepulauan Mentawai.

2. Wawancara

Wawancara adalah komunikasi langsung dengan maksud tertentu Penelitian mewawancarai satu persatu informan kunci dan informan non kunci untuk mengumpulkan data yang berkaitan dengan peranan kepemimpinan dalam meningkatkan disiplin pegawai di Dinas 
Perhubungan, Komunikasi dan Informatika Kabupaten Kepulauan Mentawai.

\subsection{Sumber Data}

1. Data primer

Adalah data yang diambil langsung oleh peneliti dalam proses wawancara yang berkaitan dengan bagaimana kepemimpinan dalam meningkatkan disiplin pegawai di Dinas Perhubungan, Komunikasi dan Informatiak Kabupaten Kepulauan Mentawai.

2. Data Sekunder

Data sekunder adalah data yang di peroleh atau yang dikumpulkan oleh orang yang melakukan penelitian dari sumber-sumber yang telah ada. Sumber tertulis dapat dibagi atas sumber buku dan majalah ilmiah, sumber dari arsip, dokumen pribadi dan dokumen resmi, data ini biasanya dari perpustakaan atau dari laporan dari peneliti terdahulu. Data sekunder disebut juga data tersedia.

\section{Penyajian}

Merupakan proses yang menggambarkan dari keseluruhan kelompok data yang diperoleh agar mudah dibaca secara menyeluruh, sehingga peneliti dapat memahami jawaban dari permasalahan yang diteliti.

4. Interpretasi Data

Dalam artian pemakanan data yaitu memberikan arti yang signifikan terhadap analisis dan menjelaskan pola uraian dan mencari hubungan antara dimensi-dimensi uraian.

\section{Penarikan Simpulan}

Data yang diperoleh dicari maknanya kemudian disimpulkan dan disajikan dalam bentuk uraian dengan menggunakan kata-kata dan kalimat yang mudah dimengerti. 


\section{HASIL PENELITIAN DAN PEMBAHASAN}

\subsection{Penerapan Gaya Kepemimpianan Demokratik Terhadap Peningkatan}

Kinerja Aparatur Pada Dinas Perhungan, Komunikasi dan Informatika Kabupaten Kepulauan Mentawai.

Menurut Kasubag Umum dan Kepegawaian bahwa penerapan kepemimpinan dalam meningkatkan disiplin pegawai di Dinas Perhubungan, Komunikasi dan Informatika Kabupaten Kepulauan Mentawai sudah berjalan dengan baik, Salah satu Indikatornya adalah pemimpin mengetahui bidang tugas masing-masing stafnya. Pemimpin mengetahui kebijakan yang telah digariskan dalam tujuan organisasinya, sehingga pelaksanaan kerja para pegawainya dapat diselesaikan dengan apa yang telah diperintahkan. Mengetahui bidang tugasnya dan selalu mengarahkan pegawainya mentaati peraturan yang di tetapkan kedisiplinan pegawai dapat terlaksana dengan baik.

Untuk meningkatkan disiplin pegawai di Dinas Perhubungan, Komunikasi dan Informatika Kabupaten Kepulauan Mentawai, maka cara yang ditempuh oleh Kepala Dinas Perhubungan, Komunikasi dan Informatika adalah melaksanakan fungsi kepemimpinan dengan meningkatkan kepekaan dan tanggap terhadap lingkungan yang seperti peka terhadap situasi dalam interen kantor, keadaan pegawai, dan lingkungan yang berkaitan dengan suasana kerja pegawai. Kepekaan itu ditunjukkan dengan seringnya pimpinan berdialog secara familiar dengan pegawai khusunya menyangkut pekerjaan di kantor dan lingkungan kerjanya. Sementara Hubungan yang dilakukan dalam pelaksanaan kerja dengan pegawainya oleh pimpinan dapat penulis amati sebagai hubungan dengan melakukan pendekatan-pendekatan melalui komunikasi secara tatap muka. 


\subsection{Kendala-kendala yang dihadapi pimpinan dalam penerapan gaya kepemimpinan demokratik terhadap kinerja aparatur pada Dinas Perhubungan, Komunikasi dan Informatika Kabupaten Kepulauan \\ Mentawai.}

Beberapa kendala yang dihadapi dalam meningkatkan kinerja pegawai seperti berikut ini :

a. Tidak mengetahui bidang tugasnya

adanya pejabat dan staf belum memahami bidang tugasnya yang baru.Ini kemudian menjadi kendala dalam meningkatkan kinerja, karena baik pejabat terlebih staf harus belajar lagi dari awal untuk memahami bidang tugasnya baru. Lebih diperparah lagi karena terkadang belum memahami bidang tugasnya yang baru tiba-tiba ada lagi mutasi ke dinas lain.

b. Tidak peka terhadap lingkungan

Kurang pekanya Pegawai terhadap Peraturan dapat mendorong Pegawai untuk tidak disiplin. Misalnya aturan kantor harus masuk pagi masih sering diabaikan pegawai yang terlambat datanag tanpa ada perasaan bersalah.

c. Kurangnya kesadaran pegawai terhadap tanggung jawabnya

Masih adanya pegawai yang kurang menyadari pentingnya komunikasi dua arah ini, bisa berakibat terjadi penumpukan pekerjaan pada satu tangan, dan ini disebabkan karena pegawai lebih banyak diam dan tidak berkomunikasi dengan yang lain dalam menyelesaikan pekerjaan kantor.

d. Kurangnya koordinasi

kurangnya koordinasi anatara pimpinan dan staf pegawai.Kondisi ini kemudian berdampak pada kurangnya tingkat kinerja pegawai dalam menjalankan tugas-tugas yang ditentukan sebelumnya.

e. Kurang tegas pengambilan keputusan 
proses pengambilan keputusan pimpinan terkadang mengabaikan suasana dan situasi pegawainya.Kondisi ini menyebabkan keputusan itu kurang efektif.

\subsection{Upaya-upaya yang dilakukan dalam menanggulangi kendala pimpinan} untuk penerapan gaya kepemimpinan demokratik terhadap kinerja aparatur pada Dinas Perhubungan, Komunikasi dan Informatika Kabupaten Kepulauan Mentawai.

upaya-upaya yang dilakukan untuk menegakkan kinerja pegawai di lingkungan Dinas Perhubungan, Komunikasi dan Informatika di Kabupaten Kepulauan Mentawai.

a. Mengetahui bidang tugasnya

Berdasarkan hasil penelitian diperoleh hasil bahwa Kepala Dinas Perhubungan, Komunikasi dan Informatika Kabupaten Kepulauan Mentawai mengetahui bidang tugasnya serta wewenang dan tanggungjawab selaku pimpinan dengan mempelajari kebijakan yang berlaku di kantor yang dipimpinnya.

b. Peka terhadap lingkungan

Dalam rangka meningkatkan kinerja pegawainya tidak terlepas dari faktor tersebut, terutama dalam menentukan kebijakan untuk meningkatkan kinerja pegawainya Kepala Dinas Perhubungan, Komunikasi dan Informatika harus peka terhadap lingkungan kerja dan keadaan pegawainya dalam melakukan pekerjaan benar-benar disipin dan dapatbertanggung jawab terhadap tugas yang diberikan kepadanya

c. Melakukan komunikasi dua arah dengan pegawainya

Berdasarkan pengamatan penulis terlihat adanya komunikasi dua arah dengan pegawainya, yaitu melalui rapat-rapat maupun secara kekeluargaan yaitu melalui monitoring pada masing-masing bidang, namun masih ada juga ada pegawai yang melakukan pelanggaran disiplin 


\section{d. Kordinasi}

Berdasarkan wawancara penulis dengan Kepala Dinas Perhubungan, Komunikasi dan Informatika Kabupaten Kepulauan Mentawai dan beberapa unsur pimpinan, diperoleh keterangan bahwa koordinasi terhadap pegawai belum dapat dilaksanakan terus menerus dan menyeluruh. Hal ini disebabkan adanya kesibukan dari Kepala Dinas dalam melaksanakan dan menyelesaikan pekrjaan sehingga Kepala Dinas kurang menruh perhatian terhadap hasil kerja pegawainya.

e. Pengambilan keputusan

Dengan adanya kemampuan Kepala Dinas Perhunungan, Komunikasi dan Informatika dalam mengambil keputusan akan diketahui kemampuan pegawai dalam melaksankan pekerjaannya serta dapat mengarahkan pegawainya untuk selalu meningkatkan disiplin kerja.

\section{E. PENUTUP}

\subsection{Kesimpulan}

1. Untuk meningkatkan disiplin pegawai di Dinas Perhubungan, Komunikasi dan Informatika Kabupaten Kepulauan Mentawai, maka cara yang ditempuh oleh Kepala Dinas Perhubungan, Komunikasi dan Informatika adalah melaksanakan fungsi kepemimpinan dengan meningkatkan kepekaan dan tanggap terhadap lingkungan yang seperti peka terhadap situasi dalam interen kantor, keadaan pegawai, dan lingkungan yang berkaitan dengan suasana kerja pegawai.

2. Kendala yang terjadi diatanya, adanya pejabat dan staf belum memahami bidang tugasnya yang baru.Ini kemudian menjadi kendala dalam meningkatkan kinerja, kurangnya koordinasi anatara pimpinan dan staf pegawai.Kondisi ini kemudian berdampak pada kurangnya tingkat kinerja pegawai dalam menjalankan tugas-tugas yang ditentukan sebelumnya 
3. Berdasarkan hasil penelitian diperoleh hasil bahwa Kepala Dinas Perhubungan, Komunikasi dan Informatika Kabupaten Kepulauan Mentawai mengetahui bidang tugasnya serta wewenang dan tanggungjawab selaku pimpinan dengan mempelajari kebijakan yang berlaku di kantor yang dipimpinnya.

\section{F. DAFTAR PUSTAKA}

Davis,2013, Bagaimana memimpin dan mengawasi pegawai anda,Jakarta: PT.Reneka Cipta.

Ndraha,2003, Kybernologi Ilmu Pemerintahan Baru (Jilid 1), Jakarta ,PT.Rieneka Cipta

Rivai, 2003, Kepemimpinan dan perilaku Organisas, Jakarta, PT.Raja Grafindo Persada

Siagian dan Sondan P, 1992, Proses Pengelolaan Pembangunan Nasional, Jakarta, PT Gunung Agung 
